\title{
Intraocular Lymphoma Models
}

\author{
Mary E. Aronow ${ }^{a} \quad$ Defen Shen $^{a} \quad$ Jacob Hochman $^{\mathrm{b}}$ Chi-Chao Chan ${ }^{\mathrm{a}}$ \\ a Laboratory of Immunology, National Eye Institute, National Institutes of Health, \\ Bethesda, Md., USA; ${ }^{b}$ Department of Cell and Developmental Biology, Alexander Silberman \\ Institute of Life Sciences, Hebrew University of Jerusalem, Jerusalem, Israel
}

\section{Key Words}

Lymphoma · Primary vitreoretinal lymphoma - T-cell lymphoma · B-cell lymphoma

Experimental model $\cdot$ Mouse $\cdot$ Eye

\begin{abstract}
Primary vitreoretinal lymphoma (PVRL) is a subtype of primary central nervous system lymphoma (PCNSL), a high-grade, extranodal, non-Hodgkin's lymphoma, predominantly of B-cell origin. PVRL is an aggressive disease with a poor prognosis. Human studies are not ideally suited for the study of intraocular lymphoma pathogenesis or treatment strategies due to the rare nature of the disease, its variable presentation, limited volume of available ocular fluids, and fragility of sampled lymphoma cells. Animal models have been critical in making progress in understanding intraocular lymphoma pathogenesis and investigating potential therapeutic strategies. Early murine models for intraocular lymphoma used intraperitoneal injection of mouse T-cell lymphomas. This was followed by intravitreal T-cell murine models. More recent murine models have used B-cell lymphomas to more closely mimic human disease. The most current B-cell lymphoma models employ a combined approach of inoculating both the mouse vitreous cavity and brain. The challenge in murine models for intraocular lymphoma lies in recreating the clinical features, disease behavior, molecular profile, systemic immunity, and the microenvironment observed in human disease. In the future, animal models will continue to be central to furthering our understanding of the disease and in the investigation of potential treatment targets.

(C) 2015 S. Karger AG, Basel
\end{abstract}

\section{Introduction}

Primary vitreoretinal lymphoma (PVRL) is a subtype of primary central nervous system lymphoma (PCNSL), a high-grade, extranodal, non-Hodgkin's lymphoma. The prognosis is poor for individuals with PCNSL, with a median survival ranging from 1 to 8 years depending 
on factors such as age and Karnofsky performance status [1,2]. While typically of B-cell origin (diffuse large B-cell lymphoma), rare cases of primary T-cell PVRL occur [3] but are usually secondary to human T-cell lymphotropic virus type 1 or metastatic T-cell lymphoma $[1,4,5]$. Among immunocompetent individuals, the peak incidence of PVRL is between the ages of 50 and 70 years. In immunocompromised populations, PVRL is observed at a younger age [6-8]. Clinically, PVRL is characterized by vitreous cells and sub-retinal pigment epithelium (RPE) infiltrates comprised of aggregated lymphoma cells $[9,10]$. Anterior segment findings such as keratic precipitates, aqueous cells, flare, and iris nodules may be encountered, but are nonspecific and less common $[8,11]$. Central nervous system (CNS) involvement tends to be periventricular in location, thus allowing access to the cerebrospinal fluid and leptomeninges. The association between PVRL and PCNSL is variable, with CNS disease occurring prior to, following, or simultaneously with ocular presentation. An estimated $25 \%$ of patients with PCNSL will have concomitant ocular disease at the time of diagnosis [12]. In contrast, 56-85\% of individuals with PVRL will ultimately develop CNS involvement [13-16].

Animal models have provided the best means by which to study the pathogenesis of PCNSL and PVRL. While it is believed that these lymphomas originate from late- or postgerminal center lymphoid cells [17-19], the neurotropic mechanisms by which cells localize to the CNS is complex, and at present, these mechanisms are not completely understood [20]. It has been hypothesized and demonstrated in some studies that the trafficking of lymphoma cells from the brain to the eye and vice versa involves invasion of the optic nerve, seeding through shared venous drainage of the brain and eye, or common integrin or chemokine expressions of both organs [21-23]. Human studies are not ideal for the study of lymphoma pathogenesis due to the rare nature of the disease, its variable presentation, limited volume of available ocular fluids (anterior chamber and vitreous), and fragility of sampled lymphoma cells. For these reasons, animal models have been critical in furthering our understanding of the disease mechanisms underlying intraocular lymphoma pathogenesis and for the development of newer therapeutic strategies (table 1).

The earliest work of intraocular lymphoma animal models was undertaken by White and colleagues [24, 25] who performed direct heterotransplantation of lymphoblasts from the peripheral blood of a child with T-cell acute lymphoblastic leukemia into the anterior chambers of nude mice. This work resulted in the establishment of 18 lymphoid xenograft cell lines, which were maintained intraocularly in the nude mouse for further study and characterization [25]. This early model created the foundation for developing animal models of intraocular lymphoma, which more closely resembled the human disease state. The majority of early murine models for intraocular lymphoma that followed were predominantly of T-cell lineage [26-29]. To more closely simulate human intraocular lymphoma, B-cell murine models were eventually created [30-33]. As animal models for intraocular lymphoma continue to evolve, aspects such as the tissue distribution of lymphoma infiltration and whether or not the trafficking pattern of lymphoma cells closely mimics the human disease state have offered important practical considerations.

\section{T-Cell Murine Models for PVRL}

\section{Intraperitoneal Inoculation of Lymphoma Cells}

In 1997, Assaf et al. [26] were the first to develop a T-cell murine model for intraocular lymphoma. This model focused on understanding the trafficking patterns of lymphoma cells injected at a remote anatomic site. In this model, intraperitoneal inoculation of variant S49 mouse lymphoma cells (designated Rev-2-T-6) was performed in infant syngeneic BALB/c mice at the ages of 6-60 days. The mice that were inoculated between days 6 and 
Table 1. Animal models in intraocular lymphoma

\begin{tabular}{|c|c|c|c|}
\hline Reference, year & Cell line & Recipient/site & Lymphoma distribution \\
\hline $\begin{array}{l}\text { T-cell models } \\
\text { Assaf et al. [26], 1997 } \\
\text { Hochman et al. [28], } 2001\end{array}$ & $\begin{array}{l}\text { Murine } \mathrm{H} 2^{\mathrm{d}} \text { Rev-2-T-6 } \\
\text { (from S49) }\end{array}$ & $\begin{array}{l}\text { BALB/c mice } \\
\text { Intraperitoneal }\end{array}$ & $\begin{array}{l}\text { Eyelids, orbit, anterior } \\
\text { chamber, optic nerve, brain }\end{array}$ \\
\hline Chan et al. [27], 2005 & $\begin{array}{l}\text { Murine } \mathrm{H} 2^{\mathrm{d}} \text { Rev-2-T-6 } \\
\text { (from S49) }\end{array}$ & $\begin{array}{l}\text { BALB/c mice } \\
\text { Vitreous }\end{array}$ & $\begin{array}{l}\text { Vitreous, } \\
\text { subretinal space }\end{array}$ \\
\hline Hochman et al. [29], 2013 & $\begin{array}{l}\text { Murine } \mathrm{H} 2^{\mathrm{d}} \text { Rev-2-T-6 } \\
\text { (from S49) } \\
\text { Anti-LFA-1/CD11a }\end{array}$ & $\begin{array}{l}\text { BALB/c and SCID mice } \\
\text { Vitreous (lymphoma } \\
\text { cells) } \\
\text { Intraperitoneal } \\
\text { (antibody) }\end{array}$ & $\begin{array}{l}\text { Choroid, sclera, conjunctiva, } \\
\text { eyelids, orbit, optic nerve } \\
\text { sheath, optic tract, brain, } \\
\text { contralateral eye }\end{array}$ \\
\hline $\begin{array}{l}\text { B-cell models } \\
\text { Li et al. [30], } 2006\end{array}$ & Human CA46 & $\begin{array}{l}\text { SCID mice } \\
\text { Vitreous }\end{array}$ & $\begin{array}{l}\text { Vitreous, subretinal space, } \\
\text { sub-RPE space, choroid, brain }\end{array}$ \\
\hline Touitou et al. [31], 2007 & $\begin{array}{l}\text { Murine } \mathrm{H}^{\mathrm{d}} \text { IIA1.6 } \\
\text { (from A20-2J) }\end{array}$ & $\begin{array}{l}\text { BALB/c mice } \\
\text { Vitreous }\end{array}$ & $\begin{array}{l}\text { Vitreous, retina, anterior } \\
\text { chamber, iris, ciliary body, } \\
\text { choroid }\end{array}$ \\
\hline Mineo et al. [32], 2008 & $\begin{array}{l}\text { Human CD20-transfected } \\
\text { murine B-cell lymphoma } \\
(38 \mathrm{C} 13 \text { CD20+) }\end{array}$ & $\begin{array}{l}\mathrm{C} 3 \mathrm{H} / \mathrm{HeN} \text { mice } \\
\text { Vitreous } \\
\text { Caudate nucleus }\end{array}$ & $\begin{array}{l}\text { Vitreous, subretinal space, } \\
\text { anterior chamber, orbit, brain } \\
\text { (only when caudate nucleus } \\
\text { inoculated) }\end{array}$ \\
\hline $\begin{array}{l}\text { Ben Abdelwahed et al. [33], } \\
2013\end{array}$ & $\begin{array}{l}\text { Murine A20.IIA-GFP- } \\
\text { hCD20 }\left(\mathrm{H} 2^{\mathrm{d}}\right)\end{array}$ & $\begin{array}{l}\text { BALB/c mice } \\
\text { Vitreous } \\
\text { Cerebral striatum }\end{array}$ & $\begin{array}{l}\text { Vitreous, brain, cervical lymph } \\
\text { nodes }\end{array}$ \\
\hline
\end{tabular}

SCID = Severe combined immunodeficiency .

11 developed disease involvement in both the eye and the CNS. This was most apparent on day 7 in the majority (58\%) of mice. In the mice that were inoculated after postnatal day 11 , no signs of tumor extension were noted. Histopathological analysis revealed that intraperitoneal inoculation resulted in tumor infiltration of a wide distribution of tissues including the eyelids, orbit, intraocular tissues (including the anterior chamber), optic nerve, and brain [26]. The same authors used their model to further explore the trafficking patterns of lymphoma cells by performing a histopathological analysis in inoculated mice at fixed time points [28]. They demonstrated that infiltration of the brain and eyes could be visualized as early as days 9 and 14 after intraperitoneal inoculation, respectively. They also determined histopathologically that lymphoma cells entered the brain preferentially through the choroid plexus and cranial nerves [28]. The involvement of rostral CNS structures occurred prior to that of caudal structures within the brain. Trafficking of lymphoma cells to the eye was demonstrated histologically to occur through migration along the optic nerve sheath, with continued spread along the choroid, ciliary body, and iris into the anterior chamber [28]. The orbit was also infiltrated by the lymphoma cells; however, this occurred independently of the brain-optic nerve-intraocular route. There was no evidence in this model to support retrograde infiltration of the lymphoma cells from the eye to the brain [28]. This early murine model provided one of the first opportunities to investigate the route of infiltration to the eyes and brain as well as the underlying mechanisms that control these trafficking patterns. 
Ocular Oncology

and Pathology

\begin{tabular}{l|l}
\hline Ocul Oncol Pathol 2015;1:214-222 \\
\hline DOI: $10.1159 / 000370158$ & $\begin{array}{l}\text { ( 2) 2015 S. Karger AG, Basel } \\
\text { www.karger.com/oop }\end{array}$ \\
\hline
\end{tabular}

Aronow et al.: Intraocular Lymphoma Models

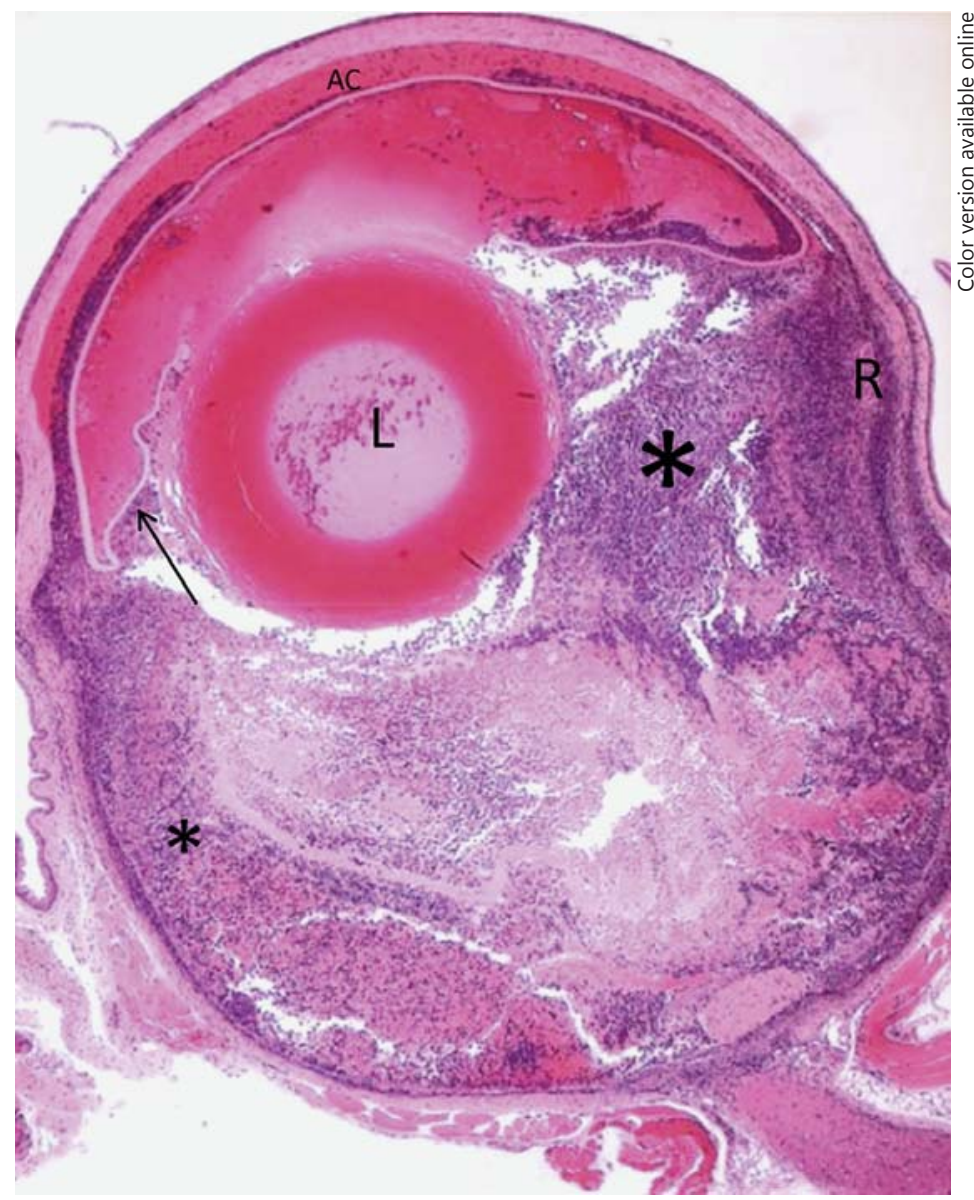

Fig. 1. Photomicrograph of an eye of a BALB/c mouse inoculated with intravitreal Rev-2-T-6 cells. Lymphoma cells are contained in the vitreous, retina, and uvea. Necrosis and destruction are present in the retina. Hemorrhages are filled in the anterior chamber. The lens shows matured cataracts (AC = anterior chamber; $\mathrm{L}=$ lens; $\mathrm{R}=$ retina). The asterisks show lymphoma cells, and the arrow shows the lens capsule. HE. $\times 50$.

\section{Intravitreal Inoculation of Lymphoma Cells}

Subsequently developed T-cell intraocular lymphoma animal models used a direct inoculation of lymphoma cells into the vitreous cavity. Chan et al. [27] used Rev-2-T-6 lymphoma cells (at concentrations of $0.5 \times 10^{5}$ or $1.0 \times 10^{5}$ ) for the injection into the vitreous cavity of adult BALB/c mice. Following injection, the mice were monitored clinically every other day and underwent weekly fundoscopic examination. The eyes were studied histopathologically at fixed time points of $3,5,6,7$, or 8 weeks following inoculation [27]. With direct inoculation into the vitreous cavity, migration of tumor cells from the vitreous to the subretinal space was observed at the 2- to 4-week time point. Trafficking of lymphoma cells through the RPE and invasion of the choroid and sclera rarely occurred, and this phenomenon was observed at late time points ( 2 months) following inoculation. This finding was important and emphasized the protective barrier function of the RPE. No retrograde spread from the eyes to the CNS was observed. The extent of tumor infiltration within the various tissues (fig. 1) was also confirmed using immunohistochemistry with an antibody specific to the Rev-2-T-6 lymphoma cells [27].

Using this model, cytokine transcript (mRNA) expression $(I L-2, I L-4, I L-6, I L-10$, and IFN- $\gamma$ ) as well as CC chemokine receptor-1 (CCR1) was assayed in the lymphoma cells using microdissection and reverse transcription polymerase chain reaction (RT-PCR). In this model, intraocular lymphoma cells produced high levels of $I L-10, I F N-\gamma$, and CCR1 transcripts. High levels of cytokines (IL-10 and IL-6) measured by enzyme-linked immunosorbent assay (ELISA) were also found to be present in the vitreous cavities of mice inoculated with 
Aronow et al.: Intraocular Lymphoma Models

Rev-2-T-6 cells [27]. This T-cell murine model demonstrated that intraocular lymphoma could be established in mice with histopathologic features and cytokine profiles that closely mimicked disease in humans.

Hochman et al. [29] further developed the intravitreal T-cell murine model by combining the intravitreal inoculation of Rev-2-T-6 cells in BALB/c mice with repeated intraperitoneal injections of anti-LFA-1/CD11a monoclonal antibody. LFA-1 is a member of the integrin superfamily of adhesion molecules and is expressed on the surface of leukocytes. It is involved in multiple aspects of regulating inflammation and immune function including endothelial cell adhesion, migration across endothelial cells, immune synapse structure and function, targeted cell death by cytotoxic T cells, costimulation, differentiation of naive $\mathrm{T}$ cells to Th1 effector lymphocytes, antiapoptotic activity, and cell trafficking [29].

The addition of repeated intraperitoneal injections of anti-LFA-1/CD11a monoclonal antibody resulted in extensive tissue infiltration by lymphoma cells including the choroid, sclera, conjunctiva, eyelids, and orbit. A new finding in this model was that lymphoma cells were observed to metastasize in a retrograde manner along the optic nerve sheath into the brain and through the optic tract into the contralateral eye [29]. Furthermore, intraperitoneal injections of anti-LFA-1 antibody resulted in elevated levels of serum anti-Rev-2-T-6 antibodies. This finding was significant, as the confinement of Rev-2-T-6 lymphoma cells to the eye depends on the active immune surveillance using a population of effector cells expressing LFA-1. Anti-LFA-1 treatment did not only affect the lymphoma cells but also the retinal resident cells with enhancing expression of adhesion and inflammatory molecules and receptors. Interestingly, this treatment showed less effect on the increase in ICAM-1 production from ocular resident cells than from lymphoma cells (fig. 2). This model was also important as it demonstrated that the disruption of this protective immune mechanism resulted in more aggressive tumor behavior and the ability of early retrograde lymphoma metastasis into the brain and the contralateral eye.

\section{B-Cell Murine Models for PVRL}

\section{Intravitreal Inoculation of Lymphoma Cells}

As the vast majority of human intraocular lymphomas are of B-cell origin, there has been significant interest in developing B-cell murine models for PVRL. In an early B-cell murine model for intraocular lymphoma, Li et al. [30] performed intravitreal injection of a human B-cell lymphoma (cell line CA46) at concentrations ranging from 6,000 cells per injection to 200,000 cells per injection in severe combined immunodeficient mice. The cell line CA46 was first confirmed by flow cytometry to express critical markers including C-X-C chemokine receptor type 4 (CXCR4, which binds to stromal cell-derived factor-1), CXCR5 (which binds to B-cell chemoattractant), and CD22 (surface marker on mature and some immature B cells). The combination of these markers is vital in the pathogenesis of PVRL [34]. CA46 cells were also shown by quantitative RT-PCR to express the B-cell growth factor/anti-inflammatory cytokine IL-10, which is both a pathogenic factor as well as an important diagnostic marker for human PVRL [30]. Fundoscopic examination, histopathology, and immunohistochemistry were then performed. Histopathologic examination revealed tumor establishment as early as day 10 after inoculation. Lymphoma cells were shown to initially infiltrate the retinal surface, followed by migration through the retina, expansion within the subretinal space, and eventually metastasis beyond the RPE into the choroid. Lymphoma spread into the CNS was also observed in this model.

A second aim of this model was to investigate the efficacy of immunotoxin HA22 as a potential therapy for PVRL. Immunotoxins are recombinant proteins that take advantage of 


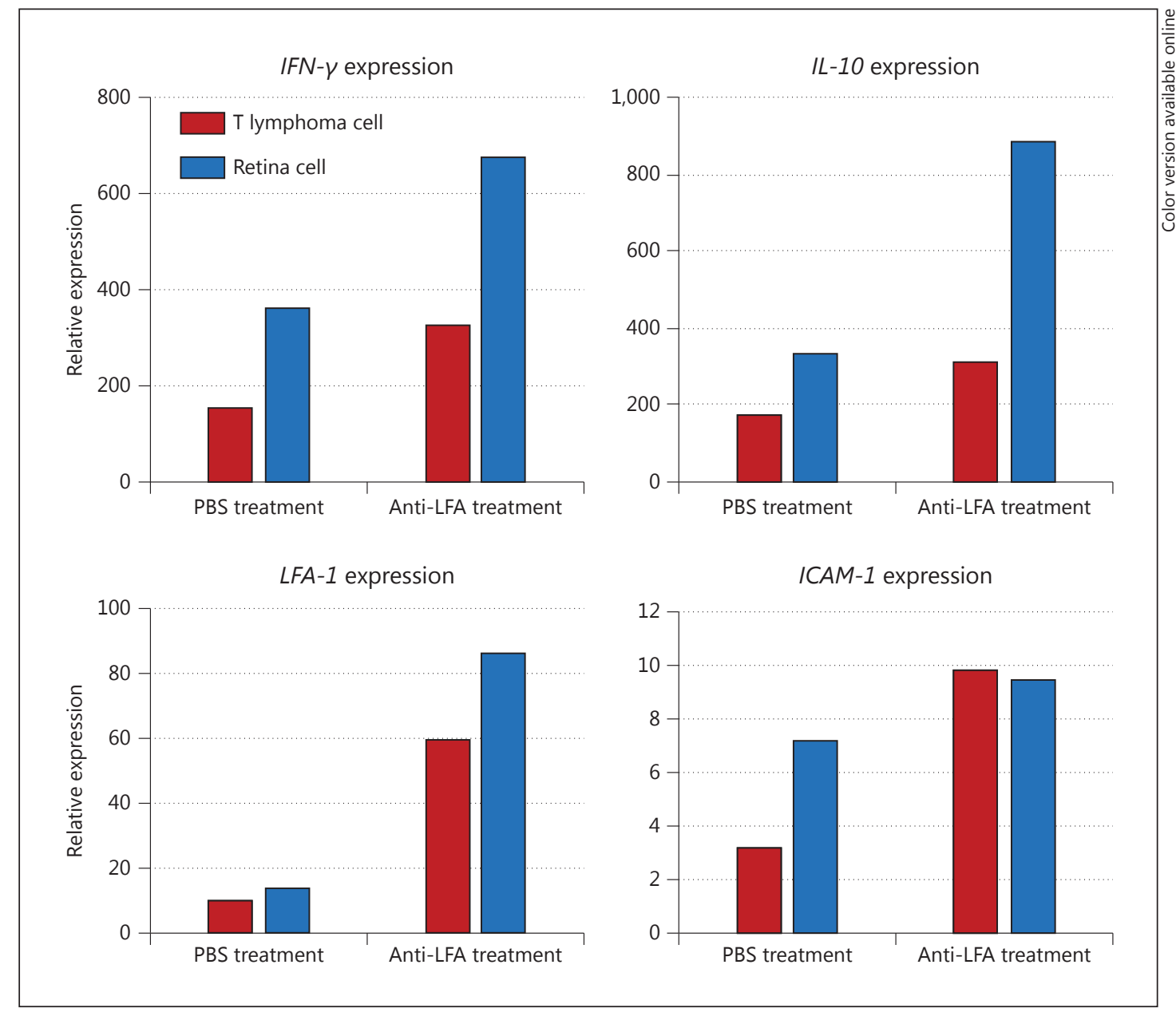

Fig. 2. Expression of $I F N-\gamma, I L-10, L F A-1$, and $I C A M-1$ transcripts in the lymphoma and noninfiltrated retina. Anti-LFA-1 treatment enhances the expression of $I L-10$ and adhesion molecule mRNAs in the lymphoma and retinal resident cells that could promote tumor invasion and further metastasis. Both lymphoma and noninfiltrated retinal cells were microdissected, and the respective transcripts were measured with quantitative RT-PCR. Relative expression is the fold changes of the specific tested mRNA.

cytotoxic properties of exotoxins and simultaneously have the specificity of monoclonal antibodies to ensure target-specific cell death. Immunotoxin HA22 is a mutated form of BL22, an immunotoxin that specifically targets B-cell lymphoma expressing CD22. HA22 results in increased antitumor properties in the absence of increased animal toxicity [35]. Li et al. [30] demonstrated that a single intravitreal injection of immunotoxin HA22 in murine eyes with established lymphoma could cause complete tumor regression [23]. This early B-cell murine model of intraocular lymphoma was shown to closely mimic human PVRL both clinically in terms of tissue distribution and also in regard to the expression of important in vivo markers and the cytokine profile. Additionally, this model showed that B-cell-specific immunotoxin therapy might have important therapeutic implications in treating human disease.

Soon afterwards, Touitou et al. [31] created a new murine model using intravitreal inoculation to study the immune microenvironment in intraocular lymphomas and to characterize the cytokine polarization of tumor-infiltrating $\mathrm{T}$ lymphocytes (TILs). Immunocompetent adult mice were injected intravitreally with a syngeneic lymphomatous B-cell line. The 
Aronow et al.: Intraocular Lymphoma Models

IIA1.6 cells were derived from A20-2J murine B-cell lymphoma ( $\mathrm{H}{ }^{\mathrm{d}}$ ) [36]. Following intravitreal injection, clinical, histopathologic, and flow cytometric investigations were performed to assess the tissue distribution of lymphoma involvement and immune infiltration. Intraocular lymphoma involvement was observed on day 19 , predominantly within the retina and the vitreous cavity. The anterior chamber, iris, ciliary body, and choroid were also involved in some mice. Anterior chamber invasion with keratic precipitates, flare, and vitreous haze were observed after day 7 if more than $5 \times 10^{4}$ cells were injected, but only after day 14 for mice injected with $10^{4}$ or fewer lymphoma cells. Vasculitis, optic nerve edema, or retinal detachment was observed after day 21 in some cases. No lymphoma spread to the fellow eyes or the CNS was observed [31].

Studying the immune microenvironment using this model demonstrated that up to $15 \%$ of viable cells were $\mathrm{T}$ lymphocytes following the establishment of intraocular lymphoma on day 19. Cytokine profile analysis of the supernatant of intraocular cells cultured ex vivo confirmed the presence of IL-10, IL-6, IFN- $\gamma$, and TNF- $\alpha$. Stimulation of these intraocular cells with anti-CD3 and anti-CD28 antibodies increased the IFN- $\gamma$ level and resulted in subsequent IL-2 production, consistent with a type 1 (Th1/Tc1-like) pattern of cytokine expression [31]. In contrast, IL-12p70 and IL-4, potent Th1 or Th2 differentiating factors, were undetectable following stimulation. These findings were important as they suggested that TILs from intraocular B lymphoma are characterized by a Th1/Tc1-like profile, which was partially inhibited in vivo by a lack of IL-2 in the absence of T-cell stimulation. This suggests a potential therapeutic role for in situ T-cell stimulation to reactivate Th1/Tc1 lymphocytes and improve intraocular immunity against lymphoma progression.

\section{Combined Intravitreal and Cerebral Inoculation of Lymphoma Cells}

Mineo et al. [32] developed a murine model to evaluate the efficiency of intravitreal and intracerebral anti-CD20 monoclonal antibody (rituximab). In this model, human CD20-transfected murine B-lymphoma cells (38C13 CD20+) were inoculated in the vitreous cavity or in the brain caudate nucleus of immunocompetent syngeneic mice. The mice were monitored clinically, by fundoscopic examination, and histopathologically. Inoculation of lymphoma cells into the vitreous or CNS resulted in tumor occurrence after a median of 15 or 22 days, respectively. In mice that underwent intravitreal inoculation, tissue infiltration by lymphoma cells was observed histopathologically in the vitreous, subretinal space, anterior chamber, and orbit. Involvement of the CNS was observed only in mice that underwent inoculation of lymphoma cells within the caudate nucleus. Local rituximab (a chimeric monoclonal antibody against CD20) injections eradicated the lymphoma in more than half of the mice and resulted in the significant inhibition of tumor progression in the remainder. In contrast, mice that were inoculated with a control cell line (38C13 CD20-) demonstrated progression of lymphoma despite rituximab injection. Similarly, mice that were inoculated with 38C13 CD20+lymphoma cells and subsequently treated with local injection of trastuzumab, an irrelevant antibody against human epithelial receptor type 2, also demonstrated disease progression. This dual model of intravitreal and cerebral inoculation of human lymphoma cells in immunocompetent syngeneic mice provided a practical method for evaluating both the pathogenesis and potential treatment of PVRL and PCNSL using local administration of rituximab.

More recently, Ben Abdelwahed et al. [33] developed a combined intravitreal and cerebral murine model of intraocular lymphoma to study the effects of ublituximab, a glycoengineered chimeric monoclonal anti-human CD20 monoclonal antibody that may enhance antibodydependent cell-mediated cytotoxicity compared to rituximab. A murine lymphoma B-cell line A20.IIA-GFP-hCD20 $\left(\mathrm{H}^{2} 2^{\mathrm{d}}\right)$ was injected into either the cerebral striatum $\left(5 \times 10^{4}\right.$ in $\left.2 \mu \mathrm{l}\right)$ or the vitreous cavity $\left(10^{4}\right.$ in $\left.2 \mu \mathrm{l}\right)$ of immunocompetent adult BALB/c $\left(\mathrm{H}-2^{\mathrm{d}}\right)$ mice. Mouse survival was monitored, and histopathological examination was performed. Using these 
Aronow et al.: Intraocular Lymphoma Models

methods, lymphomatous infiltration was observed in the vitreous, CNS, and cervical lymph nodes of mice. Lymphoma trafficking occurred via direct migration from the vitreous or the CNS. After 4-7 days, ublituximab (1, 5, or $20 \mu \mathrm{g})$ was injected either intracerebrally or intravitreally. A single dose of ublituximab, injected either into the brain or vitreous, resulted in both a significant decrease in tumor burden and an increase in survival compared to mice treated with rituximab $(20 \mu \mathrm{g})$. These early results suggested a potential role for ublituximab as therapy for PVRL and PCNSL.

\section{Future Directions}

PVRL is a highly aggressive disease with a poor prognosis that is difficult to study in humans owing to its rare nature, variable presentation, limited volume of available ocular fluids, and fragility of sampled lymphoma cells [37,38]. Current animal models have provided the best available means by which to study the disease pathogenesis of PVRL as well as potential therapeutic targets. Murine and potentially other animal models will continue to be critical in furthering our understanding of PVRL pathogenesis. The challenge lies in creating a model that closely mimics the clinical features (phenotypes: tissue distribution of lymphoma involvement and tissue responses to lymphoma infiltration), disease behavior (pathological and immunological: trafficking patterns of lymphoma cells), molecular profiles, immunological and vascular influences, and the microenvironment observed in human disease [37]. In the future, recreating these features in murine and other animal models will continue to be imperative in order to further our understanding of the disease process and in the investigation of potential novel treatment strategies.

\section{References}

1 Abrey LE, Ben-Porat L, Panageas KS, Yahalom J, Berkey B, Curran Wet, et al: Primary central nervous system lymphoma: the Memorial Sloan-Kettering Cancer Center prognostic model. J Clin Oncol 2006;24:5711-5715.

-2 Aronow ME, Schachat AP, Peereboom DM, Singh AD: Primary vitreoretinal lymhoma; in Ryan SJ (ed): Retina. London, Saunders Elsevier, 2013, vol 3, pp 2373-2378.

-3 Coupland SE, Anastassiou G, Bornfeld N, Hummel M, Stein H: Primary intraocular T-cell lymphoma: report of a case and review of the literature. Graefes Arch Clin Exp Ophthalmol 2005;243:189-197.

4 Marshall AG, Pawson R, Thom M, Schulz TF, Scaravilli F, Rudge P: HTLV-I associated primary CNS T-cell lymphoma. J Neurol Sci 1998;158:226-231.

5 Coupland SE, Foss H-D, Assaf C, Auw-Hädrich C, Anastassiou G, Anagnostopoulos I, Hummel M, Karesh JW, Lee WR, Stein H: T-cell and T/natural killer-cell lymphomas involving ocular and ocular adnexal tissues: a clinicopathologic, immunohistochemical and molecular study of 7 cases. Ophthalmology 1999;106:2109-2120.

6 6 Babu K, Murthy KR, Krishnakumar S: Two successive ocular malignancies in the same eye of a HIV-positive patient: a case report. Ocul Immunol Inflamm 2010;18:101-103.

7 Mathai A, Lall A, Jain R, Pathengay A: Systemic non-Hodgkin's lymphoma masquerading as Vogt-KoyanagiHarada disease in an HIV-positive patient. Clin Exp Ophthalmol 2006;34:280-282.

-8 Rajagopal R, Harbour JW: Diagnostic testing and treatment choices in primary vitreoretinal lymphoma. Retina 2011;31:435-440.

-9 Dean JM, Novak MA, Chan CC, Green WR: Tumor detachments of the retinal pigment epithelium in ocular/ central nervous system lymphoma. Retina 1996;16:47-56.

10 Gass JD, Sever RJ, Grizzard WS, Clarkson JG, Blumenkranz M, Wind CA, et al: Multifocal pigment epithelial detachments by reticulum cell sarcoma. A characteristic funduscopic picture. Retina 1984;4:135-143.

11 Akpek EK, Ahmed I, Hochberg FH, Soheilian M, Dryja TP, Jakobiec FA, et al: Intraocular-central nervous system lymphoma: clinical features, diagnosis, and outcomes. Ophthalmology 1999;106:1805-1810.

12 Hochberg FH, Miller DC: Primary central nervous system lymphoma. J Neurosurg 1988;68:835-853.

13 Peterson K, Gordon KB, Heinemann MH, DeAngelis LM: The clinical spectrum of ocular lymphoma. Cancer 1993;72:843-849.

14 Cassoux N, Merle-Beral H, Leblond V, Bodaghi B, Miléa D, Gerber S, et al: Ocular and central nervous system lymphoma: clinical features and diagnosis. Ocul Immunol Inflamm 2000;8:243-250. 
Ocular Oncology

and Pathology
Ocul Oncol Pathol 2015;1:214-222

DOI: $10.1159 / 000370158$

Aronow et al.: Intraocular Lymphoma Models

(C) 2015 S. Karger AG, Basel www.karger.com/oop

15 Char DH, Ljung BM, Miller T, Phillips T: Primary intraocular lymphoma (ocular reticulum cell sarcoma) diagnosis and management. Ophthalmology 1988;95:625-630.

-16 Freeman LN, Schachat AP, Knox DL, Michels RG, Green WR: Clinical features, laboratory investigations, and survival in ocular reticulum cell sarcoma. Ophthalmology 1987;94:1631-1639.

-17 Coupland SE, Loddenkemper C, Charlotte F, Smith J, Hummel M, Stein H: Expression of immunoglobulin transcription factors in primary central nervous system lymphoma and primary intraocular lymphoma. Invest Ophthalmol Vis Sci 2005;46:3957-3964.

18 Montesinos-Rongen M, Küppers R, Schlüter D, Spieker T, Van Roost D, Schaller C, Reifenberger G, Wiestler OD, Deckert-Schlüter M: Primary central nervous system lymphomas are derived from germinal-center B cells and show a preferential usage of the V4-34 gene segment. Am J Pathol 1999;155:2077-2086.

19 Malumbres R, Davis J, Ruiz P, Lossos IS: Somatically mutated immunoglobulin IGHV@ genes without intraclonal heterogeneity indicate a postgerminal centre origin of primary intraocular diffuse large B-cell lymphomas. Br J Haematol 2007;138:749-755.

20 DeAngelis LM: Primary central nervous system lymphoma. Curr Opin Neurol 1999;12:687-691.

21 Pe'er J, Hochberg FH, Foster CS: Clinical review: treatment of vitreoretinal lymphoma. Ocul Immunol Inflamm 2009;17:299-306.

22 Jahnke K, Coupland SE, Na IK, Loddenkemper C, Thiel E, Keilholz U, Scheibenbogen C: Expression of the chemokine receptors CXCR4, CXCR5 and CCR7 in primary central nervous system lymphoma. Blood 2005; 106:384-385.

-23 Smith JR, Falkenhagen KM, Coupland SE, Chipps TJ, Rosenbaum JT, Braziel RM: Malignant B cells from patients with primary central nervous system lymphoma express stromal cell-derived factor-1. Am J Clin Pathol 2007; 127:633-641.

24 White L, Meyer PR, BenedictWF: Establishment and characterization of a human T-cell leukemia line (LALW-2) in nude mice. J Natl Cancer Inst 1984;72:1029-1038.

25 White L, Trickett A, Norris MD, Tobias V, Sosula L, Marshall GM, et al: Heterotransplantation of human lymphoid neoplasms using a nude mouse intraocular xenograft model. Cancer Res 1990;50:3078-3086.

-26 Assaf N, Hasson T, Hoch-Marchaim H, Pe'er J, Gnessin H, Deckert-Schlüter M, et al: An experimental model for infiltration of malignant lymphoma to the eye and brain. Virchows Arch 1997;431:459-467.

-27 Chan CC, Fischette M, Shen D, Mahesh SP, Nussenblatt RB, Hochman J: Murine model of primary intraocular lymphoma. Invest Ophthalmol Vis Sci 2005;46:415-419.

-28 Hochman J, Assaf N, Deckert-Schluter M, Wiestler OD, Pe'er J: Entry routes of malignant lymphoma into the brain and eyes in a mouse model. Cancer Res 2001;61:5242-5247.

29 Hochman J, Shen D, Gottesman MM, Chan CC: Anti-LFA-1 antibodies enhance metastasis of ocular lymphoma to the brain and contralateral eye. Clin Exp Metastasis 2013;30:91-102.

30 Li Z, Mahesh SP, Shen de F, Liu B, Siu WO, Hwang FS, et al: Eradication of tumor colonization and invasion by a B cell-specific immunotoxin in a murine model for human primary intraocular lymphoma. Cancer Res 2006; 66:10586-10593.

-31 Touitou V, Daussy C, Bodaghi B, Camelo S, de Kozak Y, Lehoang P, et al: Impaired th1/tc1 cytokine production of tumor-infiltrating lymphocytes in a model of primary intraocular B-cell lymphoma. Invest Ophthalmol Vis Sci 2007;48:3223-3229.

32 Mineo JF, Scheffer A, Karkoutly C, Nouvel L, Kerdraon O, Trauet J, et al: Using human CD20-transfected murine lymphomatous B cells to evaluate the efficacy of intravitreal and intracerebral rituximab injections in mice. Invest Ophthalmol Vis Sci 2008;49:4738-4745.

-33 Ben Abdelwahed R, Donnou S, Ouakrim H, Crozet L, Cosette J, Jacquet A, et al: Preclinical study of ublituximab, a glycoengineered anti-human CD20 antibody, in murine models of primary cerebral and intraocular B-cell lymphomas. Invest Ophthalmol Vis Sci 2013;54:3657-3665.

34 Chan CC: Molecular pathology of primary intraocular lymphoma. Trans Am Ophthalmol Soc 2003;101:275292.

-35 Bang S, Nagata S, Onda M, Kreitman RJ, Pastan I: HA22 (R490A) is a recombinant immunotoxin with increased antitumor activity without an increase in animal toxicity. Clin Cancer Res 2005;11:1545-1550.

$\$ 36$ Jones B, Tite JP, Janeway CA Jr: Different phenotypic variants of the mouse B cell tumor A20/2J are selected by antigen- and mitogen-triggered cytotoxicity of L3T4-positive, I-A-restricted T cell clones. J Immunol 1986; 136:348-356.

-37 Chan CC, Rubenstein JL, Coupland SE, Davis JL, Harbour JW, Johnston PB, et al: Primary vitreoretinal lymphoma: a report from an International Primary Central Nervous System Lymphoma Collaborative Group symposium. Oncologist 2011;16:1589-1599.

-38 Chan CC, Sen HN: Current concepts in diagnosing and managing primary vitreoretinal (intraocular) lymphoma. Discov Med 2013;15:93-100. 